NGTT Deel 54, Nommers 3 \& 4, September en Desember 2013

Thesnaar, Christo ${ }^{1}$

Stellenbosch University

\title{
Reformed Churches struggle for justice: Lessons learnt from their submissions before the TRC
}

\begin{abstract}
The Truth and Reconciliation Commission (TRC) arranged a special hearing for all faith communities in relation to their contribution to human rights violations under apartheid. This forced different faith groupings and Christian denominations to recollect their role in the struggle for justice in South Africa. Two prominent Reformed Churches made submissions to the TRC on how they have dealt with the history of apartheid in relation to the struggle for justice. Their submissions were made up of different themes as they reflected on their role in the struggle for justice within South Africa's apartheid's past (within the time frame 1960 to 1990). This contribution aims to highlight and discuss some of the most prominent themes in the struggle for justice from the two Reformed Churches as they reflected on the apartheid past and to identify some lessons from among these themes that the church community can use in order to empower the church to redeem the past and contribute to healing and reconciliation in the present and future.
\end{abstract}

"But our future must be founded on the truth of the past. The Word of God teaches us that the truth makes us free!" Jan Marais (submission of the presbytery of the DRC Stellenbosch in Paarl).

\section{INTRODUCTION}

The Truth and Reconciliation Commission (TRC) $)^{2}$ received submissions from different faith groupings and Christian denominations in reaction to a call from the TRC for a special hearing for all faith communities in relation to human rights violations under apartheid. This contribution will specifically focus on how the Dutch Reformed Church (DRC) ${ }^{3}$ and the Uniting Reformed Church in South Africa (URCSA) ${ }^{4}$ have dealt with the history of apartheid in their submissions before the TRC.

In relation to their struggle for justice, "remembrance" and "memory"5 are key elements for both victims and perpetrators within the two churches. Given their vast different backgrounds and experiences of the traumatic past and the way these formed their own identities, it is obligatory for healing and reconciliation that they remember the past and share it in public with each other. Suppressed and forgotten truth is part of the inclusive $\operatorname{truth}^{6}$ which must be uncovered if a polarised society is to be united in the healing process and form a communal identity.

1 Christo Thesnaar is lecturer in pastoral care and counselling

2 The TRC was officially established and maintained by Parliament in July 1995 with the task to find the truth of what happened in South Africa between the $1^{\text {st }}$ of March 1960 and the $5^{\text {th }}$ of December 1993.

3 The General Synod, a regional synod and a presbytery of the DRC made official submissions to the TRC.

4 URCSA, as well as the Messina URCSA congregation also submitted official submissions to the TRC.

5 See the article by Prof F. Deist, in Die Kerkbode, 8/9 September 1996, p 5.

6 Also see Villa-Vicencio (1995:114). 
NGTT: Oopbron - http://ngtt.journals.ac.za

How we understand truth is essential to how we are able to make our past redemptive. This was emphasised by Archbishop emeritus Desmond Tutu when he stated, "There can be no healing without truth" (TRC Report of South Africa, vol. 4. 1998:115). The TRC argued vigorously that truth should also be understood as healing and restorative truth over and against a factual and objective understanding of truth. This supports the movement towards a more comprehensive understanding of truth, namely: relational, personal, subjective and narrative understanding of truth.

The aim of this contribution is firstly to highlight and discuss some of the most prominent themes in the struggle for justice from the two Reformed Churches as they reflected on the apartheid past (within the time frame of 1960 to 1990) in their submissions before the TRC. Secondly, the aim is to make a constructive contribution toward dealing with the past and contributing to healing and reconciliation by identifying some lessons learnt from the themes discussed. The goal of these lessons is to empower the church to redeem the past, live in the present and move towards the future.

\section{Prominent themes in the Submissions}

\subsection{Submission before the TRC?}

The DRC was very hesitant about making a submission before the TRC. Leading up to the inception of the TRC and thereafter the Afrikaans media was prominent in spreading negative rhetoric ${ }^{7}$ regarding the TRC. It referred to the TRC as a witch-hunt ${ }^{8}$ and a one-sided process where the Afrikaner will be placed in the dock. ${ }^{9}$ The effect of this negative rhetoric created scepticism and mistrust among the Afrikaans community towards dealing with the apartheid past and in particular the work of the TRC. ${ }^{10}$

The DRC did nonetheless take thorough cognisance of the aim and work of the TRC. ${ }^{11}$ It made a conscious decision to support the work of the TRC with prayer as early as the end of 1995 and specifically requested the TRC to act fairly to all sides (Meiring 1999:20). Meiring, ${ }^{12}$ as a member of the TRC and member of the DRC, urged the DRC to participate in the TRC process by giving its support, pastorally caring for the victims and perpetrators (and their families) and to pray for the Commission. He also assured them that it will be an opportunity for witness if the DRC could submit a report that will not only explain their role during the last three decades but will help future generations to understand how the church felt about apartheid, why they did what they did and what they failed to do. ${ }^{13}$ The call by Meiring to participate in

\footnotetext{
7 See Meiring (1999:96 - 97).

8 See Meiring (1999:61).

9 See Meiring (1999:96).

10 See F.M. Gaum in Die Kerkbode, 2 February 1996, p. 6; and F.M. Gaum in Die Kerkbode, 1 March 1996 , p. 6.
}

11 Also see F.M. Gaum in Die Kerkbode, 1 March 1996, p. 1; F.M. Gaum in Die Kerkbode, 29 March 1996, p. 4; Brand, D, in Die Kerkbode, 2 February 1996, p. 6; Janse van Rensburg, J A, in Die Kerkbode, 14/15 June1996, p 13; Swanepoel, Freek, in Die Kerkbode, 16 August1996, p. 6; Koornhof, H in Die Kerkbode, 16 August 1996, p 14; F.M. Gaum in Die Kerkbode, 6 September 1996, p. 6; Prof Sas Strauss, in Die

Kerkbode, 11 December 1996, p 4 and Dr DD Roslee, 18 July 1997, p. 6.

12 See F.M. Gaum in Die Kerkbode, 13/14 September 1996, p. 6.

13 See F.M. Gaum in Die Kerkbode, 13/14 September 1996, p. 6. 
NGTT Deel 54, Nommers $3 \& 4$, September en Desember 2013

the TRC process was supported by the then Moderator of the DRC, Rev. Freek Swanepoel ${ }^{14}$ as well as the decision by the DRC in the Eastern Cape to call on its members to testify before the TRC (Meiring 1999:86).

The submission by the DRC Presbytery of Stellenbosch at the TRC hearing in Paarl ${ }^{15}$ was indeed a response to the call from Meiring as well as a prophetic and significant step by any religious organisation, especially the DRC to start dealing with their role in the apartheid past. ${ }^{16}$ The public and the commissioners present were all touched by the submission but soon it was clear that not everybody within the DRC was as excited as they were. ${ }^{17}$ In an editorial in Die Kerkbode18 the editor stated in no uncertain terms, that the Presbytery of Stellenbosch has placed the General synod of the DRC in a very difficult situation and that their submission only indicated the role of the DRC in the dark part of our history.

In spite of this criticism the Western and Southern Cape Synod of the DRC continued to become the only regional synod of the DRC to submit a report ${ }^{19}$ to the TRC at its extraordinary synodal meeting held on the $7^{\text {th }}$ to the $9^{\text {th }}$ of October 1997. It is however commendable that the Northern Transvaal Synod, although deciding against submitting a report to the TRC, missed the opportunity by a mere 18 votes out of the 400 present. $^{20}$

The General Synodal Commission (GSC) initially decided by a majority of three votes not to submit an official confession before the TRC (Meiring, 1999:95). ${ }^{21}$ Instead of an official submission the GSC requested Dr Frits Gaum to compile a document (Journey with Apartheid) to explain the journey of the DRC with Apartheid to its congregants and others who may be interested. The TRC could then have access to the document from the church regarding their journey with Apartheid that they could reflect on if they preferred to do so. Fortunately, after the DRC was invited to a special hearing for all the religious communities in East London, on the $14^{\text {th }}$ of November 1997, the GSC decided to send its Moderator to make a submission before the TRC. Even though the entire DRC was not in agreement that the moderator should do a submission on behalf of the DRC it was still seen as a significant moment by many people in and outside of the church. ${ }^{22}$

There was no hesitancy from the URCSA to submit a submission to the TRC. Their goal was to provide the TRC with a clear reflection of their understanding of being church under Apartheid. ${ }^{23}$ In their own words: "The historical and contemporary self-understanding of the church, as portrayed in this slogan ("The Church - Site of Struggle"), is that the church as one of the institutions in society did not remain unaffected by the all-encompassing influence of apartheid" (URCSA submission 1997:4).

14 See Prof P Meiring, in Die Kerkbode, 2 August 1996, p 1 and Dr Hannes Koornhof, in Die Kerkbode, 16 August 1996, p. 22.

15 TRC hearing in Paarl was from the $14^{\text {th }}-16^{\text {th }}$ of October 1996.

16 The submission was done by Prof Bethel Muller and Rev Jan Marais on behalf of the Presbytery of

Stellenbosch DRC.

17 See the letter by Dr G Griesel, in Die Kerkbode, 6 December 1996, p. 6.

18 See F.M. Gaum in Die Kerkbode, 18 October 1996, p 1.

19 See the submission of the Western and Southern Cape Synod of the DRC on the $20^{\text {th }}$ of October 1997.

20 See F.M. Gaum in Die Kerkbode, 3 October 1997, p. 9.

21 Those in support, see F.M. Gaum in Die Kerkbode, 1 August 1997, p. 7. And those saddened by the

decision see F.M. Gaum in Die Kerkbode, 15 August 1997, p. 7.

22 See F.M. Gaum in Die Kerkbode, 21 November 1997, p. 1 \& Meiring 1999:265-285.

23 See Meiring 1999:279 -280. 
NGTT: Oopbron - http://ngtt.journals.ac.za

\subsection{Support of Apartheid}

From the outset the DRC provided theological and Biblical sanction for political praxis of apartheid, even though some of its theologians argued to the contrary (General Synodal Commission, Journey with Apartheid, 1997:15, 4.4.3). The church continued to play an active role in supporting and promoting ${ }^{24}$ apartheid on practical or cultural grounds. As stated in the Journey with Apartheid (1997:7, 2.5), the DRC urged the government to implement the policy of apartheid and therefore many of the laws were instituted with the approval of the church. This is an evident example of the entwined relationship between the DRC and the white Afrikaner community. The DRC is sometimes referred to as the "National Party at prayer". The result of this intertwined relationship is that there can hardly be space for anybody else: "It was on account of its profound and justifiable identification with the destiny of the people whom it served in the first instance - the Afrikaners - that the Dutch Reformed Church often tended to put the interests of its people above those of other people" (Journey with Apartheid, 1997:36, 9.9).

The DRC actively supported the military offence against the enemies of the state in order to endorse the policies of Apartheid. According to the TRC Report of South Africa (vol. 4. 1998:66), many state operatives claimed to have found positive support in DRC teachings and received the church's "blessings" (for) their weapons of terror. When Rev Neels Du Plooy, a military chaplain, testified before the TRC and called the deeds of the apartheid government the "apartheid war" he was rebuked by the editor of Die Kerkbode in an editorial that affirmed the real danger of communism. ${ }^{25}$ As indicated in the response by the editor of Die Kerkbode, it is evident that the DRC too often not only accepted state propaganda regarding the 'Communist onslaught', but gave credence to it in justifying its support for government policy and the 'total war' strategy against liberation forces (General Synodal Commission, Journey with Apartheid, 1997:30, 7.1-7.2 \& 9.2.1). Indeed, on its own admission, the DRC became a paid servant of the state's propaganda arm, the Department of Information (Journey with Apartheid, 1997:15, 4.6.1). In this regard it is safe to say that for members of the DRC and URCSA the participation of chaplains reinforced the acceptance of the apartheid cause in their minds and often demonised their opponents (TRC Report of South Africa, vol. 4. 1998:67).

Initially the URCSA was in support of apartheid, mainly due to being part of the larger DRC church family, and, as indicated earlier, being dominated for many years by conservative white missionaries. This virtually placed the church in a position where they had no choice but to accept the theology which legitimised apartheid and to remain silent about the ways the apartheid policy was implemented. This reality and the Calvinistic theology as it was preached formed the mentality of the church and its members, making them compliant to this policy and critical of those who sought to take an anti-apartheid position. The URCSA confesses that it failed to live up to its faith convictions, that it found it difficult to implement its decisions against apartheid in practical action, and in many cases watered them down, that it did not give the necessary support to young people and those who suffered or to organisations engaged in the struggle against apartheid (URCSA submission to the TRC, 1997:10). Indeed, it states that the "absence of decisions and actions represent a blatant omission and silent approval of the conditions and main cause of human rights violations" (URCSA submission to the TRC, 1997:6 \& 9).

24 See TRC Report of South Africa, vol. 4. 1998:66.

25 See F.M. Gaum in Die Kerkbode, 1 August 1997, p. 6. 
NGTT Deel 54, Nommers 3 \& 4, September en Desember 2013

\subsection{Opposition to Apartheid}

Faith communities across the board spoke of opposing apartheid, although the language and practices through which they expressed this opposition differed widely (TRC Report of South Africa, vol. 4. 1998:79). There were continuous voices and publications from within the DRC that challenged its support of apartheid, such as the DRC theologians attending the Cottesloe Church Conference; ${ }^{26}$ that of Dr Beyers Naude, the journal Pro Veritate, Prof Nico Smith; the "Ope Brief" (open letter) supported by 123 ministers in 1982; ${ }^{27}$ Prof Jonker's confession at the Rustenburg conference, and many others. Instead of listening to these voices and publications, the church (national and local) chose to ignore them and rather slanted and libelled them. ${ }^{28}$ Some were even personally victimised.

Given the extent of the intertwined relationship with the government of the time, the DRC decided to follow the route of confidential discussions with members of the government concerning issues such as "detention without trial, and to request that the policies be applied with compassion and humanity" (General Synodal Commission, Journey with Apartheid, 1997:4.21; TRC Report of South Africa, vol. 4. 1998:80). At best, the DRC did at times request the authorities to implement the policy fairly, though on its own admission the request was seldom made forcefully or consequently monitored. It was, in fact, just too theoretical, "The church did not take enough trouble to establish whether, in practice, this policy complied at all with the stated norms of love and righteousness" (General Synodal Commission, Journey with Apartheid, 1997:9.5 \& 9.15, 4.21). The only real opposition to government legislation mentioned in the DRC submission had to do with the so called "church clause" of the Native Laws Amendment Act of 1957 (Journey with Apartheid, 1997:2.5.4).

The Cottesloe Church Conference ${ }^{29}$ was indeed a turning point in the history of apartheid. The DRC participated in the conference by means of the then Transvaal DRC and the Cape DRC being members of the World Counsel of Churches. The resolutions accepted at the conference caused sharp criticism within the church and government circles. This reaction was based on resolutions that directly opposed laws of government that were supported by the church, such as those covering mixed marriages, job reservations, land tenure and co-determination, and the political status of the so called coloureds. Not only did the strong figures within the DRC such as Dr A. P. Treurnicht and Dr J. D. Vorster react heavily but also the then Prime Minister Dr H. F. Verwoerd was outspoken in this regard (General Synodal Commission, Journey with Apartheid, 1997:10 - 11). The result of this reaction by the then Prime Minister was that it set a precedent for state interference, not simply in the affairs of the DRC (with which it already enjoyed a special relationship), but in those of the ecumenical churches (TRC Report of South Africa, vol. 4. 1998:81).

The DRC far too easily surrendered to pressure from the government. Based on this relationship it is safe to state that the DRC failed to provide any significant guidance to its membership on the biblical demand for justice in society (General Synodal Commission, Journey with

26 See General Synodal Commission, Journey with Apartheid, 1997, 15 -16.

27 See the TRC Report of South Africa, vol. 4. 1998:82.

28 The DRC Synod chose to react strongly against the voices in Pro Veritate. See Algemene Sinodale

Kommissie, Reis met Apartheid, 1997, p. 21.

29 This was a conference that was organised by the initiative of the World Council of Churches in direct reaction to the Sharpeville riots in March 1960 where 60 people were killed (General Synodal Commission,Journey with Apartheid, 1997, p.9). 
NGTT: Oopbron - http://ngtt.journals.ac.za

Apartheid, 1997:36). Rather than critically examine the actual implementation of apartheid, it preferred not to know the details of what was happening as a result of such policies as the Group Areas Act (a policy supported by the DRC) or in security police actions - even though much of it was perpetrated by its own members (Journey with Apartheid, 1997:38, 9.22 \& 24). The DRC failed to maintain the desirable critical distance in relation to the government as it was expected from a prophetic church and therefore failed dismally in their opposition to Apartheid.

From the end of the 1970's, the URCSA became increasingly critical of apartheid. ${ }^{30}$ This became evident with the emergence of indigenous leadership within the church, with the breaking of the influence of the white missionaries and with the growth to a mature theology against oppression did one detect greater clarity and urgency in the criticism of this policy (Homeland policy (migratory labour) and the Group Areas Act) on synod level ((URCSA submission to the TRC, 1997:6). In 1982 the synod of the then Dutch Reformed Mission Church declared that its resolution of 1978 implied that it had no choice "but, with the deepest regret to accuse the Dutch Reformed Church of theological heresy and idolatry in the light of (the Dutch Reformed Church's) theologically formulated stance and implementation thereof in practice" (Journey with Apartheid, 1997:17). The apartheid situation in South Africa and the stance of the DRC on it, declared the Synod of the Dutch Reformed Mission Church, created a status confessionis. This decision was in line with the resolution adopted by the World Alliance of Reformed Churches earlier that same year when it suspended the membership of the Dutch Reformed Church (Journey with Apartheid, 1997:17). ${ }^{31}$ The aspects that gave impetus to the URCSA's opposition to apartheid was the leadership and role of Dr Allen Boesak; ${ }^{32}$ the Confession of Belhar ${ }^{33}$ with its clear statement: "Therefore, we reject ideology which would legitimate forms of injustice and any doctrine which is unwilling to resist such an ideology in the name of the gospel" (URCSA submission to the TRC, 1997:13); and support for the Kairos Document ${ }^{34}$ with its clear criticism of State and Church Theology and an exposition of a Prophetic Theology (URCSA submission to the TRC, 1997:13-14).

\subsection{Victims and perpetrators of Apartheid}

It is fair to say that there were victims and perpetrators on both sides of the apartheid spectrum and that one person can be a victim and a perpetrator at the same time. Although, given the extent and impact of the apartheid policy on the churches discussed in this article, it is safe to conclude that the victims ${ }^{35}$ of apartheid were mainly the Black and Coloured members of URCSA. ${ }^{36}$ The general URCSA submission and that of the URCSA Messina congregation both indicated in no uncertain terms what the impact of the apartheid policy was on its members. The impact was not limited to a structural level but was also evident on an economical, physical, psychological, and spiritual level.

To illustrate the devastating impact of apartheid on their members they named some key

30 See URCSA submission to the TRC, 1997, pp. 18-19.

31 See URCSA submission to the TRC (1997:12 -19) for other actions that was taken by the church and documented in the submission.

32 See URCSA submission to the TRC, 1997, p. 12.

33 See the TRC Report of South Africa, vol. 4. 1998:83.

34 See the TRC Report of South Africa, vol. 4. 1998:82.

35 See Thesnaar 2011:32.

36 See TRC Report of South Africa, vol. 4. 1998:75. 
NGTT Deel 54, Nommers $3 \& 4$, September en Desember 2013

issues in their submissions: Separate churches due to colour of skin; black and white ministers who supported the struggle for liberation were often the target of the security forces; group areas act; forced removals; members resettled in different places; lost property (schools and churches) $)^{37}$ that had to be rebuilt in other areas with all the costs involved; detained without trial; arrested; tortured; persecuted; subsidies withdrawn; racism; migrant labour; poor education; ${ }^{38}$ destructions of home and family life; structural and emotional violence; prohibition of mixed marriages; caught up in the 'holy war' against communism; polarisation; indescribable suffering; victims of bombings; ${ }^{39}$ grieved materially, psychologically and physically ${ }^{40}$ (URCSA submission, 1997:20 - 21).

Perpetrators ${ }^{41}$ of the victims of apartheid, given the focus of this article were mainly the members of the DRC. Perpetrators cannot be limited to only those who actively violated the human rights of others but also include those who were bystanders who said or did nothing, and those who were beneficiaries from the apartheid system, either economically, politically, physically, socially or in religious respect.

\subsection{Confession of guilt}

Confession of guilt ${ }^{42}$ was another of the central themes in the submissions and yet the most contentious of the themes. In the general and theological discussions leading up to the TRC and during the time of the TRC it became evident that there were within the DRC vast theological differences and opinions regarding the understanding of confession.

Firstly, there were those who blatantly believed that there wasn't any wrongdoing in what they did during the time of apartheid. Everything they were involved in could be justified and therefore confession of guilt was totally unnecessary. ${ }^{43}$

Secondly, there are those who argued strongly that confession of guilt is only done before God and it is only God that can forgive our sins. ${ }^{44}$ There was therefore no room for a confession before a godless government creation that paid huge salaries for their commissioners while others were suffering (Meiring, 1999:95). ${ }^{45}$ They also seriously questioned why only the white community needed to confess and not those who were against apartheid, given the fact that so many white people were the victims of murders, rapes, etc. on a daily basis.

There are thirdly, those who argued that confession is an important part of the Christian doctrine and that Christians only need to individually confess before God and in doing so will be immediately forgiven. They therefore argued that they only needed to confess once for what they have done, on a specific place, at a specific time and ask for forgiveness and then it would be concluded. For them, continuous and repeated confessions ${ }^{46}$ as well as collective confessions on behalf of others ${ }^{47}$ are not part of the Christian doctrine.

37 See TRC Report of South Africa, vol. 4. 1998:76-77.

38 See TRC Report of South Africa, vol. 4. 1998:76.

39 See TRC Report of South Africa, vol. 4. 1998:76.

40 See URCSA Messina congregation report to the TRC, 1997, p. 1.

41 See Thesnaar 2011:33.

42 See Jaspers (1946:32) \& Meiring (1999:62).

43 See Pollefeyt (1996:178) \& Muller, in Die Kerkbode, 1 August 1997, p. 12.

44 See the letter from Bennie Bekker, in Die Kerkbode, 14 June 1996, p. 11.

45 See the letter from Dr G Griesel, in Die Kerkbode, 6 December 1996, p. 6.

46 See the letter from Prof Ben Engelbrecht, in Die Kerkbode, 1 August 1996, p. 10.

47 See the letter by Dr G Griesel, in Die Kerkbode, 6 December 1996, p. 6. 
NGTT: Oopbron - http://ngtt.journals.ac.za

Fourthly, there are those who were of the conviction that confession of guilt should be dealt with within the church structures, and not in public before a government commission. ${ }^{48}$ The original decision by the DRC not to do a submission before the TRC but rather to compile a document (in the form of a testimony and a confession) to inform its members, ministers, synods and all other interested parties on their journey with apartheid could be seen as an example of this understanding.

Lastly, there were those who were of the conviction that the church and its members ${ }^{49}$ should confess publicly before the victims and before the TRC (as a continuous confession process, ${ }^{50}$ individually and collectively) to contribute to the healing of the nation. ${ }^{51}$ The confession by Prof Willie Jonker at the Rustenburg conference as well as the confessions by the DRC before the TRC $^{52}$ could be seen as examples of an active and public contribution on the journey towards healing the nation (Journey with Apartheid, 1997:25, 5.6.1). They profoundly responded to the challenge from Dr Beyers Naudé to motivate fellow church people to face the mirror and confess to the TRC. He said, "We, who were supposed to be the conscience of the nation, didn't succeed in preventing the most serious forms of abuse of the human conscience" (Meiring 1999:157).

The URCSA set an incredible example in terms of how it approached the central issue of confession. Keeping in mind that the URCSA is a predominantly black church and that it eventually became a leading critic of apartheid, its "confession of guilt and plea for forgiveness" which is part of its submission (URCSA submission to the TRC, 1997:11) is particularly poignant ${ }^{53}$ - certainly going much further than the DRC which gave its unqualified support to apartheid.

\subsection{Reconciliation and nation building}

From the submission by the two churches to the TRC it is evident that both made firm commitments to reconciliation and nation building of which very little materialized. The DRC moved into the role of reconciler and nation builder in a much quicker way that it would acknowledge the guilt of apartheid. The 1994 synod was dubbed the synod of reconciliation. This was mainly due to the visit by the then president, Nelson Mandela, and the confession as to the way Dr Beyers Naudé and Prof Ben Marais, and many others were treated in the past. This synod committed itself to bring about a radical improvement in the living conditions and future opportunities of people in South Africa who have been deprived of so much for so many years, and to make a meaningful contribution to reconstruction and development (Journey with Apartheid, 1997:29, 6.1.4 \& 6.1.7). It also accepted a resolution on the unity of the family of Dutch Reformed Churches which also bore the stamp of reconciliation.

The DRC also expressed a willingness and commitment to the ministry of reconciliation in South Africa. This includes striving actively "for the elimination of injustice at all levels and in all corners of society" (Journey with Apartheid, 10.3, 1-2), and contributing to the "combating

48 Also see Dr W Dreyer, in Die Kerkbode, 11 May 1996, p. 7.

49 See Rev Dirk Viljoen, in Die Kerkbode, 4 July 1997, p. 7.

50 See Prof J Müller, in Die Kerkbode, 6 September 1996, p. 3.

51 See the story of confession and forgiveness where a DRC minister, Rev Charl Coetzee played a key role to bring the perpetrator Eric Taylor, a DRC member, and the victims, the Goniwe family, together so that he could confess to them. After the confession they forgave him for what he did (see Meiring 1999:123 -

127). In this regard see the Journey with Apartheid (1997:24, 5.1.4).

52 See the submission by the presbytery of the DRC Stellenbosch, 1996, p. 1.

53 See Meiring (1999:235-236). 
NGTT Deel 54, Nommers 3 \& 4, September en Desember 2013

of poverty and illiteracy" (Journey with Apartheid, 10.3.3). Its remarkable ministry in the area of social welfare, as documented in its submission, is an indication of its potential capacity to make an important contribution in this regard (Journey with Apartheid, 8.1.1-10). The DRC also acknowledged that confession of guilt inevitably leads to restitution - the putting right of the wrong that was done. The church already began to attend to that with some of its resolutions at the General Synod of 1990. This will continue in future (Journey with Apartheid, 1997:25). ${ }^{54}$

It terms of assisting its own members who actively participated in the war on the road to healing the moderator of the Eastern Cape synod, Rev Pierre Jordaan, indicated that they have developed a plan to assist their members through this difficult time of uncertainty and pain. ${ }^{55}$ This was the first, and I dare say the only, plan by a synodal commission and by the DRC as a whole to assist the soldiers and their families to deal with the spiritual, emotional and psychological scars and the trauma of the human rights abuses in a constructive way ${ }^{56}$ in order to build a new nation.

The URCSA also provided several significant suggestions concerning the possible role of the church in contributing to reconciliation in South Africa (URCSA submission to the TRC, 1997:2123). ${ }^{57}$ These include pastoral counselling of human rights victims, enabling perpetrators of crimes to confess their guilt and seek reconciliation, the preparation of reconciliation liturgies and the holding of services of reconciliation, the erection of appropriate memorials, implementing a "process of collective visioning", and the holding of an annual national week of reconciliation.

\section{Redeeming the PASt to Live in the PRESENT AND MOVE tO the FUtURE}

Otto Frank, father of Anne Frank, in reflection on the tragic narrative of the journey of his family said years later: "We cannot change what happened anymore. The only thing we can do is to learn from the past and to realize what discrimination and persecution of innocent people means. I believe that it's everyone's responsibility to fight prejudice" (Anne Frank Museum, 2012). With this insightful thought in mind there are some lessons to be learned from the way the churches dealt with the apartheid past that should be utilised as guidelines to ensure that all churches take the responsibility to fight injustice.

\subsection{Engage with the past}

For church denominations, who had theologically supported the ideology of apartheid to eventually decide to confess and make a submission before the TRC on their role in the past 30 years is, at best, a complex, uncertain and challenging process! It is quite simple to judge and criticise the Reformed Churches in support of apartheid and to shame ${ }^{58}$ the perpetrators of apartheid within these churches. For the URCSA, a victim of apartheid, it can be as difficult to make a submission because there was always the risk to be exposed to further trauma.

However it must be emphasised that remembrance is a central part of dealing with the

54 See the article by Rev Freek Swanepoel in Die Kerkbode, 16 May 1997, p. 6 \& the submission of the

Stellenbosch presbytery of the DRC to the TRC, 1996, p. 1.

55 See F.M. Gaum in Die Kerkbode, 1 November 1996, p. 16.

56 See Meiring (1999: 112-115) and Kok, D in Die Burger, 25 October 2000, p. 13.

57 Also see the article by Rev Daniel Kuys, in Die Kerkbode, 12/13 September 1997, p. 5.

58 See Thesnaar 2007:150 - 167. 
NGTT: Oopbron - http://ngtt.journals.ac.za

past, living in the present with hope for the future. The scars of the apartheid past affect our memories. Therefore we need to be aware of the danger of destructive living memories. All South Africans share a wounded memory. In this regard sensitivity and understanding is needed towards members of both churches as they enter into a process of reconciliation and healing.

\subsection{Face the truth}

In terms of facing the past truth should be understood in a more comprehensive way than was customary. This entails a relational, personal, subjective and narrative understanding as well as a healing and transformative ${ }^{59}$ understanding of truth over and against mere "factual and objective" understanding of truth. To understand truth in this way will assist both perpetrators and victims in telling and listening to their own and others' stories regarding the past.

Did the DRC always tell the truth? Could the churches be trusted? In terms of these questions the integrity of the church should always be beyond suspicion and therefore the fact that the church had received money from the state to support its goals should be acknowledged and never be repeated.

The DRC acknowledged that the synods concentrated too much on the theory of apartheid in the light of the Bible and too little on how this policy was implemented on the ground level and the effect these actions had on the people of South Africa. ${ }^{60}$ There is a real need for the churches to give account in an honest and comprehensive way on how apartheid was implemented within their local, regional and broader communities and the effect it had on their fellow South Africans.

\subsection{Confession}

In a process of reconciliation there should be space for an individual, collective and repetitive understanding of confession. Therefore space should be created for individuals, groups, congregations, presbyteries, regional and general church bodies to confess their role in the past injustices of South Africa.

\subsection{Embody justice}

Confession should always be accompanied by remorse and followed by reparation, restitution and transformative justice. The church should embody justice by leading the way to eliminate all forms of injustices, actively combating of poverty, engaging with relevant role players to transform education, combat illiteracy, redistribute wealth, land reform, etc. Added to embodying justice is the churches commitment to the recommendations made by the TRC in terms of justice and reconciliation (Report of the TRC, Vol. 5 1998:316vv).

\subsection{Reconstruct reformed identity}

To face the truth of the past is not only a political and ideological struggle but also a deeply theological struggle. To deconstruct your own theology and in many cases your own identity and reconstruct a new understanding of God, theology and identity is a painful process. It is in essence about reconstructing reformed identity. However, it could be a profoundly beneficent process if facilitated properly.

59 See the TRC Report of South Africa, vol. 4. 1998:114.

60 See the DRC's Journey with Apartheid (1997). 
NGTT Deel 54, Nommers $3 \& 4$, September en Desember 2013

\subsection{Church leadership and communication}

Leadership is a key element in any process of oppression as well as in processes of change, transformation and uncertainty. It can either guide the church (perpetrators and victims) through the past into the present with a responsible process or it can keep the church stuck in the destructive past. Therefore, thorough communication by the church leadership on dealing with the past will largely avoid a traumatic nation to become further traumatised. This can limit the effect of destructive media campaigns that have the ability to derail any process and make people sceptical.

In their submissions, faith communities commonly confessed not only to a failure to speak, but also to a failure to act. Many communities that were in principle either in support of or opposed to apartheid found it difficult to translate strong resolutions into practical action. In the nature of institutional politics, resolutions were watered down by the time they were actually passed. This calls for faith communities to improve their operational structures.

\subsection{Church should be a prophetic voice for reconciliation}

The churches should not be so exclusive in their theology and structures that there is little room for prophetic voices. Churches should learn to listen to the prophetic voices within and outside its own ecclesiastical bounds rather than to silence and ostracise them. In relation to this the church need to keep its promises if it wants to be taken seriously as a meaningful contributor to the reconciliation process. Very little if any of the commitments made by both Reformed Churches' towards reconciling and building the nation were honoured to date.

It is the church's responsibility to pastorally care for the victims as well as perpetrators and assist them on their journey towards healing and wholeness. In this sense the church can contribute to the process of healing and reconciliation by creating safe spaces where healing as transformative truth can help people deal with the past.

\section{Conclusion}

Almost 15 years after the TRC process has been concluded Professor Russel Botman, ${ }^{61}$ the vice-chancellor of Stellenbosch University, pose very significant questions: "Has the dream of reconciliation, former president Nelson Mandela cherished for South Africa, lay in pieces? Has the ideal of nation building yielded under the pressure of prejudice, racial hate and separation?" He raised these questions after two recent incidents exposed the deep racial divide in South Africa today. What is more alarming is that this divide is also still prevalent in the so-called post 1994 generation. What we need, says Professor Botman, is a definite NO to the principle of apartheid, as well as a NO to the destructive practices of the past that are still in operation today. The key, he says, is that this message must be carried on to the youth of today and tomorrow to ensure that this destructive way to deal with the past is finally and completely abolished.

These comments are indeed an accusation to the churches who claim that they have committed themselves, in 1997, to reconciliation, nation building, restitution, development and healing. This does raise critical questions in terms of the church community's ability to claim to be the carrier of such a message to the perpetrators and victims of apartheid but

61 See Botman, in Die Burger, 2012:2. 
NGTT: Oopbron - http://ngtt.journals.ac.za

also to children and youth of today and tomorrow. The lessons learnt from the themes of the submissions by these churches to the TRC confirm that the churches are eager to commit itself to the process of reconciliation on a general level but lack the capacity to facilitate this commitment through the structures of the church so that it can be practiced by the local church community within the local context.

For churches to become trusted role players in the reconciliation process it will need to take stern cognisance of the lessons learnt from the submission to the TRC. Churches need not only to believe that they can contribute to the process of healing and reconciliation but they need to facilitate and practice that belief by creating safe spaces, on a national and local level where people can deal with the past.

\section{BiBLIOGRAPHY}

Algemene Sinodale Kommissie, 1997, Reis met Apartheid, Hugenote uitgewers, Wellington.

Anne Frank Museum, 2012, Quote by Otto Frank as part of the exhibition at the Anne Frank Museum in Amsterdam in 2012, visited: 18th July 2012.

Bekker, B., 1996, 'Ware waarheidskommissie is die drie-enige God', Die Kerkbode, 157(15), 11.

Botman, R., 2012, 'Doen dit vir Madiba', Die Burger, 23 May, p. 2.

Brand, D., 1996, 'Maak eers vrede met jou broer', Die Kerkbode, 157(2), 6.

Deist, F., 1996, 'Vergewe én onthou', Die Kerkbode, 157(30), 5.

Dreyer, W., 1996, 'WVK moet werk deur die Woord', Die Kerkbode, 157(12), p7

Engelbrecht, B., 1996, 'Hou op sanik oor NGK en apartheid', Die Kerkbode, 157(27), 10.

Gaum, F.M., 1996, 'Leiers is positief teenoor kommissie', Die Kerkbode, 157(4), 6.

Gaum, F.M., 1996, 'Gee ons n' kans vra Tutu', Die Kerkbode, 157(5), 1.

Gaum, F.M., 1996, 'Die kritiese afstand', Die Kerkbode, 157(5), 6.

Gaum, F.M., 1996, 'Stellenboschers en die Waarheidskommissie', Die Kerkbode, 157(27), 1.

Gaum, F.M., 1997, 'Die NG Kerk en die 'apartheid oorlog', Die Kerkbode, 159(3), 6.

General Synodal Commission, 1997, Journey with Apartheid, Hugenote publishers, Wellington.

Griesel, G., 1996, 'Ek sou my skaam vir die Ring van Stellenbosch', Die Kerkbode, 157(31), 7.

Janse van Rensburg, J. A., 'Beginsel van WVK in wese evangelie', Die Kerkbode, 157(15), 3.

Jaspers, K., 1946, Schriften zur Zeit: Die Schuldfrage. Ein Beitrag zur deutschen Frage, Artemis, Zurich.

Kok, D., 2000, 'Afrikaanse seuns moet hulle hartseer mág wys', Die Burger, 25 Oktober, p. 13.

Koornhof, H., 1996, 'Die WVK en ons: dis 'n tyd vir verootmoediging en gebed', Die Kerkbode, 157(22), 14.

Kuys, D., 1997, 'Kerk moet help versoen', Die Kerkbode, 159(6), 5.

Meiring, P., 1996,"n NGK-verslag kan getuienis geleentheid word', Die Kerkbode, 157(23), 5.

Meiring, P., 1999, Chronicle of the Truth Commission, Carpe Diem Books, Vanderbijlpark.

Müller, J., 1996, "NGK behoort skuldbelydenis voor die WVK te doen", Die Kerkbode, 157(22), 13.

Müller, J., 1996, 'Brief', Die Kerkbode, 159(3), 12.

Muller, J., 1997, 'Is die NG Kerk te hooghartig om voor die WVK te getuig?' Die Kerkbode, 159(3), 12.

Polleyfeyt, D., 1996, 'Het onvergeeflijke vergeven? Een etische analyse van kwaad en verzoening', in R.

Burggraeve \& J. De Tavernier (Red), Terugkeer van de wraak?, pp. 155 -178, Gooi en Sticht, Averbode.

Rosslee, D.D., 1997, 'Predikante moet na die WVK gaan', Die Kerkbode, 159(2), 6.

Strauss, S., 1996, 'WVK is nog nie partydig nie', Die Kerkbode, 157(26), 4.

Swanepoel, F., 1996, 'Neem deel aan versoeningsproses', Die Kerkbode, 157(21), 6.

Swanepoel, F., 1997, 'Versoening vra kontak', Die Kerkbode, 158(13), 6.

Swanepoel, F., 1997, 'WVK hoor oor NGK - versoening', Die Kerkbode, 159(14), 1.

Thesnaar, C.H., 2007, 'Skuld en skaamte as sleutel tot die verstaan van die oortreder binne die versoeningsproses in Suid-Afrika', Journal of Practical Theology, 22(1), 150 - 167.

Thesnaar, C.H., 2011, 'Healing the scars: A theological-hermeneutical analysis of violence from the perspectives of both perpetrators and victims', Scriptura, 106, $26-37$.

The Submission of the Stellenbosch Presbytery of the DRC before the TRC, 1996, Unpublished.

The Submission of the Western and Southern Cape synod of the DRC before the TRC, 20 October 1997, Unpublished. 
NGTT Deel 54, Nommers 3 \& 4, September en Desember 2013

Truth \& Reconciliation Commission, 1998, 'Truth and Reconciliation Commission of South Africa Report', Vol. 1, 4 \&5, Cape Town.

URCSA submission before the TRC, 1997, Unpublished.

URCSA Messina congregation submission before the TRC, 1997, Unpublished.

Villa-Vicencio, C., 1995, 'Telling One Another Stories: Towards a Theology of Reconciliation', in C. VillaVicencio and C. Niehaus (ed), Many Cultures, One Nation, pp, Human \& Rousseau, Cape Town. Viljoen, D., 1997, 'Ons moet skuld van versuim bely', Die Kerkbode, 159(1), 7.

\section{KEY WORDS}

Reformed Churches

Reconciliation

Past

Truth and Reconciliation Commission

Justice

TREFWOORDE

Gereformeerde Kerke

Versoening

Verlede

Waarheids en Versoeningskommissie

Geregtigheid

Contact details

Christo Thesnaar

Professor

University of Stellenbosch

South Africa

cht@sun.ac.za

(021) 808 - 3257 